\title{
Pre-concentration of Lithium Prior to Its Determination in Honey by Flame Optical Emission Spectrometry
}

\author{
Helena Stecka and Pawel Pohl* \\ Department of Analytical Chemistry, Faculty of Chemistry, Wroclaw University of Technology, \\ Wybrzeze Stanislawa Wyspianskiego 27, 50-370 Wroclaw, Poland
}

\begin{abstract}
Foi proposto um procedimento para a pré-concentração e determinação de traços de lítio em diferentes méis florais, empregando para a extração contínua em fase sólida uma resina de troca catiônica fortemente ácida, a Dowex 50W×8-200. Ao se eluir as soluções de méis a 10\% em massa, na coluna empacotada com a resina de troca catiônica, os íons $\mathrm{Li}^{+}, \mathrm{K}^{+} \mathrm{e} \mathrm{Na}$ foram retidos na resina enquanto que os açúcares simples não foram retidos e se encontraram integralmente nos eluatos. Os cátions $\mathrm{Li}^{+}, \mathrm{Na}^{+}$e $\mathrm{K}^{+}$foram eluídos com uma solução de $\mathrm{HCl} 1,0 \mathrm{~mol} \mathrm{~L}{ }^{-1}$ após a lavagem das colunas com água; os analitos presentes nesse eluato foram determinados por espectrometria de emissão ótica com chama (FOES). O limite de detecção instrumental (LOD) apresentado pelo método foi de $0,05 \mathrm{ng} \mathrm{g}^{-1}$ de lítio e o método foi empregado para a quantificação de Li em diversos méis naturais e comerciais. A faixa de concentração ótima para a determinação de Li foi de 0,4 a $5,3 \mathrm{ng} \mathrm{g}^{-1}$ com precisão de $8-11 \%$. A exatidão do método proposto foi avaliada por estudos de recuperação do analito e está no intervalo de 98 a 106\%, demonstrando a confiabilidade dos resultados obtidos.
\end{abstract}

A procedure based on solid phase extraction with a strongly acidic cation-exchanger Dowex $50 \mathrm{~W} \times 8-200$ was proposed to pre-concentrate and determine ultra-traces of $\mathrm{Li}$ in different floral honeys. When loading $10 \%(\mathrm{~m} / \mathrm{v})$ honey solutions onto columns packed with the cation-exchanger, $\mathrm{Li}^{+}$ions were retained on the resin along with $\mathrm{K}^{+}$and $\mathrm{Na}^{+}$, while simple sugars were passed through columns and were entirely found in effluents. In turn, columns were washed with water and eluted with a $1.0 \mathrm{~mol} \mathrm{~L}^{-1} \mathrm{HCl}$ solution to strip $\mathrm{Li}^{+}$that was subsequently determined in respective eluates by flame optical emission spectrometry (FOES). The proposed method was characterized by a limit of detection (LOD) of $0.05 \mathrm{ng} \mathrm{g}^{-1}$ of $\mathrm{Li}$ and later used for analysis of several raw and commercial mono- and multi-flower honeys. It enabled to determine from 0.4 to $5.3 \mathrm{ng} \mathrm{g}^{-1}$ of $\mathrm{Li}$ with precision being within $8-11 \%$. Accuracy of this sample pre-treatment procedure and analysis method was assessed applying spike recovery tests. Recoveries of added Li were found to be within 98 to $106 \%$, demonstrating trustworthiness of results achieved.

Keywords: lithium, honey, pre-concentration, determination, flame optical emission spectrometry

\section{Introduction}

Lithium in honey is present in trace concentrations and can primarily reach it from soil through nectar and pollen of blossom plants or secretions of living parts of plants. The content of this metal is highly variable and greatly depends on honey provenance as demonstrates data found in literature and related to concentration ranges of $\mathrm{Li}$ in honeys of different floral origin and from different countries, e.g., from not detected (ND) to $0.24 \mu \mathrm{g} \mathrm{g}^{-1}$ in

*e-mail: pawel.pohl@pwr.wroc.pl
French honeys, ${ }^{1}$ from 0.30 to $1.5 \mu \mathrm{g} \mathrm{g}^{-1}$ in Turkish honeys ${ }^{2}$ or from ND to $110 \mu \mathrm{g} \mathrm{g}^{-1}$ in Spanish honeys. ${ }^{3-9}$ Because Li, like other alkaline or alkaline earth metals present in honey, is associated with soil characteristics and specificity, and agricultural practices, it certainly well reflects geographical origin and different locality conditions. ${ }^{4-6}$ Accordingly, Li was recognized to be a useful feature accounting for successful discrimination between honeys from different regions, i.e., coastal and mountain territories, rural and urban areas. For the same reason, $\mathrm{Li}$ was also found to be a good descriptor for classification between honeys of a stated origin and those originated from an industrial processing. ${ }^{7.8}$ 
It appears however that $\mathrm{Li}$ is occasionally determined in honeys what proves a limited number of works reported so far and devoted to this metal. Inductively coupled plasma optical emission spectrometry (ICP OES) is commonly used for measuring concentrations of $\mathrm{Li}$ in honeys, typically along with other metals. ${ }^{1-6}$ Flame optical emission spectrometry (FOES), although more inexpensive than ICP OES is curiously rarely used..$^{7-10}$ In case of both mentioned techniques, samples of honey are usually calcined, followed by dissolving resulted ash in solutions of mineral acids ${ }^{3-6}$ or digested in concentrated oxidizing reagents ${ }^{1,2}$ before measuring $\mathrm{Li}$ concentrations.

Flame OES with $\mathrm{C}_{2} \mathrm{H}_{2}$-air flame seems to be quite expedient technique for measurements of $\mathrm{Li}$ with low limit of detection (LOD). ${ }^{11}$ In contrast to $\mathrm{K}$ and $\mathrm{Na}, \mathrm{Li}$ is hardly ionized in flame due to relatively high ionization potential $(5.39 \mathrm{eV})$, hence, it could be expected that high concentrations of primarily $\mathrm{K}$ and $\mathrm{Na}$ as well as $\mathrm{Ca}$ and $\mathrm{Mg}$ would have a reduced effect on Li determinations. By contrast, high organic matter contents could deteriorate the analytical response for $\mathrm{Li}$ and result in high background emission levels. ${ }^{12}$

For that reason, a solid phase extraction (SPE) procedure was developed in the present work to overcome interferences coming from simple sugars and pre-concentrate traces of $\mathrm{Li}$ before its determination in honeys by means of FOES. In addition, it was expected that this procedure would be a good alternative to commonly used acid decomposition or calcinations of honey. ${ }^{1-6}$ In advance, the effect of various concentrations of $\mathrm{K}, \mathrm{Na}$, glucose and fructose, being the most important constituents of honeys, on the Li response was studied. The sorption behavior of $\mathrm{Li}$ and mentioned constituents toward different sorption materials, including an adsorbing resin Amberlite XAD-7HP, a strongly basic anion-exchange resin Dowex $1 \times 4-200$, a strongly acidic cation-exchange resin Dowex 50W $\times 8-200$ and a mixed bed ion-exchange resin Dowex Retardion 11A8, was examined as well. For selected strong cation-exchanger, retention and recovery conditions for $\mathrm{Li}$ were optimized. Validity of a Dowex $50 \mathrm{~W} \times 8-200$ column SPE-based procedure was verified using spike recovery tests. Finally, this procedure was applied to determine $\mathrm{Li}$ in several raw and commercially marked mono- and multi-flower honeys.

\section{Experimental}

\section{Reagents and materials}

All reagents used in this work were of analytical grade. Chemicals were supplied by POCh (Gliwice, Poland). Ultra-pure water, obtained from a WIGO PRO-11G reverse osmosis water purification system (Wroclaw, Poland) was used throughout. Single element stock standard solutions of $1000 \mathrm{mg} \mathrm{L}^{-1}$ of $\mathrm{K}, \mathrm{Li}$ and Na were obtained from Merck KGaA (Darmstadt, Germany) and used to prepare mixed standard solutions of these metals for calibration. $100 \mathrm{~mL}$ working standard solutions, containing $\mathrm{K}\left(10.0 \mathrm{mg} \mathrm{L}^{-1}\right), \mathrm{Li}$ $\left(0.1 \mathrm{mg} \mathrm{L}^{-1}\right)$ and $\mathrm{Na}\left(1.0 \mathrm{mg} \mathrm{L}^{-1}\right)$ in addition to glucose and fructose, both at $10 \mathrm{~g} \mathrm{~L}^{-1}$, were prepared to study sorption properties of polymeric resins used. These solutions were acidified using a $0.010 \mathrm{~mol} \mathrm{~L}^{-1} \mathrm{HCl}$ solution to $\mathrm{pH} 3.5,4.0$, 4.5 and 5.0 which are close to the acidity of honey solutions.

Polymer-based resins were purchased from SigmaAldrich (Saint Louis, MO, USA) and included a weakly polar macro-reticular adsorbent Amberlite XAD-7HP (polyacrylic ester matrix, 20-60 mesh size, $450 \mathrm{~m}^{2} \mathrm{~g}^{-1}$ surface area), a strongly basic anion-exchanger Dowex 1×4-200 (styrene-divinylbenzene co-polymer matrix, 100200 mesh size, 1.0 mequiv. $\mathrm{g}^{-1}$ total exchange capacity for - $\mathrm{N}\left(\mathrm{CH}_{3}\right)_{3}{ }^{+}$functional group), a strongly acidic cationexchanger Dowex 50W $\times 8-200$ (styrene-divinylbenzene co-polymer matrix, 100-200 mesh size, 1.7 meq mL $\mathrm{mL}^{-1}$ total exchange capacity for $-\mathrm{SO}_{3}^{-}$functional group) and an amphoteric exchanger Dowex Retardion 11A8 (styrenedivinylbenzene co-polymer matrix, 50-100 mesh size, 1.2 and 1.1 mequiv. $\mathrm{g}^{-1}$, respectively, for $-\mathrm{COO}^{-}$and $-\mathrm{N}\left(\mathrm{CH}_{3}\right)_{3}{ }^{+}$ functional groups). Resins were packed into Sigma-Aldrich glass columns (10 $\mathrm{mm}$ i.d.) with glass coarse frits and polytetrafluoroethylene (PTFE) stopcocks. A Cole-Parmer 4-channel MasterFlex L/S peristaltic pump (Vernon Hill, IL, USA) was employed to control flow rates of solutions passed through SPE columns.

\section{Instrumentation and measurements}

Measurements of $\mathrm{K}, \mathrm{Li}$ and $\mathrm{Na}$ concentrations in effluents and eluates collected, and honey sample solutions were made with a Perkin Elmer (Norwalk, CT, USA) flame atomic absorption spectrometer, model 1100B. It was equipped with a $10 \mathrm{~cm}$ single slot burner head for a $\mathrm{C}_{2} \mathrm{H}_{2}$-air combustion flame. A sampling unit integrated with the burner comprised a plastic coated mixing chamber with a flow spoiler and an end cap with a drain interlock assembly. Solutions were continuously aspirated through a mounted stainless steel nebulizer. Working conditions for instrument operation (Table 1) were selected according to recommendations of the spectrometer manufacturer given for $\mathrm{K}, \mathrm{Li}$ and $\mathrm{Na}$ measurements in an oxidizing $\mathrm{C}_{2} \mathrm{H}_{2}$-air flame in emission mode. Time-average integration (a hold mode) with an integration time of $1 \mathrm{~s}$ and 3 read cycles was applied for signal processing. Ten replicate measurements at maximum absorption were carried out at $0.1 \mathrm{~s}$ intervals 
Table 1. Operating conditions and analytical performance for determining $\mathrm{K}, \mathrm{Li}$ and $\mathrm{Na}$ by FOES

\begin{tabular}{lccc}
\hline & $\mathrm{K}$ & $\mathrm{Li}$ & $\mathrm{Na}$ \\
\hline $\mathrm{C}_{2} \mathrm{H}_{2}$ flow rate, $\mathrm{L} \mathrm{min}^{-1}$ & 1.2 & 1.2 & 1.2 \\
Air flow rate, $\mathrm{L} \mathrm{min}^{-1}$ & 8.0 & 8.0 & 8.0 \\
Wavelength, nm & 766.5 & 670.8 & 589.0 \\
Spectral resolution, nm & 0.4 & 0.4 & 0.2 \\
Lamp current, mA & 7 & 8 & 10 \\
Upper linearity range, $\mathrm{mg} \mathrm{L}^{-1}$ & 2.0 & 0.5 & 1.0 \\
LOD, ${ }^{\mathrm{a}} \mu \mathrm{\mu g} \mathrm{L}^{-1}$ & 0.9 & 0.1 & 1.5 \\
Precision, ${ }^{\mathrm{b}} \%$ & $0.8-3.2$ & $0.5-4.1$ & $1.2-5.6$ \\
\hline
\end{tabular}

a $(3 \times \mathrm{SD}$ of average intensity signal for a water blank without $\mathrm{Li}, \mathrm{n}=5)$. ${ }^{b}$ Expressed as RSD of average intensity signals $(n=3)$ for $0.05,0.10,0.20$ and $0.50 \mathrm{mg} \mathrm{L}^{-1}\left(\mathrm{~K}\right.$ and $\mathrm{Na}$ ) and $0.01,0.02,0.05$ and $0.10 \mathrm{mg} \mathrm{L}^{-1}(\mathrm{Li})$.

and averaged in each read cycle. Sample solutions were directly analyzed against aqueous standard solutions. Three replicate measurements were made and averaged.

Concentrations of glucose and fructose in column effluents collected were measured using the SomogyiNelson spectrophotometric method. In a two-step procedure, a sample portion containing glucose and fructose with added an alkaline solution of $\mathrm{Cu}$ (II) ions was heated in a boiling water bath to reduce $\mathrm{Cu}(\mathrm{II})$ to $\mathrm{Cu}$ (I) ions. In turn, an arsenomolybdate reagent, prepared by reacting ammonium molybdate $\left[\left(\mathrm{NH}_{4}\right)_{6} \mathrm{Mo}_{7} \mathrm{O}_{24}\right]$ with sodium arsenate $\left(\mathrm{Na}_{2} \mathrm{HAsO}_{4}\right)$ in $\mathrm{H}_{2} \mathrm{SO}_{4}$, was added to produce a polymolybdate complex of intensive blue color due to a redox reaction with resulting $\mathrm{Cu}(\mathrm{I})$ ions. ${ }^{13}$ The absorbance of molybdenum blue produced was measured at $520 \mathrm{~nm}$ using a Thermo Scientific Spectronic 20D+ digital spectrophotometer (Bremen, Germany). The concentration of simple sugars was determined against suitable standard solutions containing glucose at concentrations ranging from 1 to $50 \mathrm{mg} \mathrm{L}^{-1}$. Alkaline $\mathrm{Cu}$ (II) and arsenomolybdate reagent solutions used were prepared according to reference 13 .

\section{Resin conditioning and column operation}

Amberlite XAD-7HP resin was initially dried in an oven at $110{ }^{\circ} \mathrm{C}$ for $2 \mathrm{~h}$. Portions containing $1.5 \mathrm{~g}$ of this resin were soaked with methanol and then with water, and finally poured into SPE columns as water slurries. Resin beds were conditioned by washing with $10 \mathrm{~mL}$ of methanol, followed by $20 \mathrm{~mL}$ of water. After that, they were rinsed with $10 \mathrm{~mL}$ of a $4.0 \mathrm{~mol} \mathrm{~L}^{-1} \mathrm{HCl}$ solution, and again with $40 \mathrm{~mL}$ of water to remove excessive $\mathrm{HCl}$. In case of ion-exchangers, $1.5 \mathrm{~g}$ portions were soaked with water and poured into SPE columns. Resin beds were washed with $10 \mathrm{~mL}$ of a
$4.0 \mathrm{~mol} \mathrm{~L}{ }^{-1} \mathrm{HCl}$ solution, followed by $40 \mathrm{~mL}$ of water. Thus, counter ions of functional groups of ion-exchangers were $\mathrm{H}^{+}$and/or $\mathrm{Cl}^{-}$ions. Water and conditioning solutions

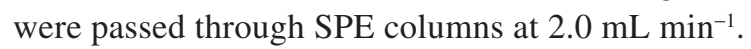

To investigate sorption behavior of resins toward $\mathrm{Li}$ ions and simple sugars under $\mathrm{pH}$ changed from 3.5 to 5.0, working standard solutions described above were passed through SPE columns at $1.0 \mathrm{~mL} \mathrm{~min}{ }^{-1}$. After passing about $80 \%$ of solutions, column effluents $(10 \mathrm{~mL})$ were collected and analyzed for $\mathrm{K}, \mathrm{Li}, \mathrm{Na}$ and glucose with fructose concentrations $\left(\mathrm{C}_{\text {effluent }}\right)$. Recovery efficiencies of $\mathrm{K}, \mathrm{Li}, \mathrm{Na}$ and simple sugars (\%) were evaluated relating concentrations of these constituents determined in effluents $\left(\mathrm{C}_{\text {effuent }}\right)$ to their original concentrations present in loaded solutions (C) according to equation $100 \times \mathrm{C}_{\text {effuent }} / \mathrm{C}$. The effect of $\mathrm{HCl}$ concentrations $\left(0.5,1.0\right.$, and $\left.2.0 \mathrm{~mol} \mathrm{~L}^{-1}\right)$ in eluting solutions on recoveries of $\mathrm{K}, \mathrm{Li}$ and $\mathrm{Na}$ ions from Dowex $50 \mathrm{~W} \times 8-200$ cation-exchanger was examined as well. Accordingly, $100 \mathrm{~mL}$ working solutions ( $\mathrm{pH} 4.0$ )

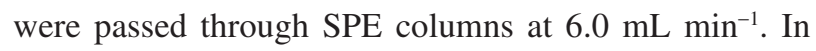
turn, metal ions retained were recovered using 5 or $10 \mathrm{~mL}$ portions of $\mathrm{HCl}$ solutions that were passed through SPE columns at $1.0 \mathrm{~mL} \mathrm{~min}^{-1}$. Volumes of 5 and $10 \mathrm{~mL}$ eluate portions were collected and analyzed for the contents of $\mathrm{K}, \mathrm{Li}$ and $\mathrm{Na}\left(\mathrm{C}_{\text {eluate }}\right)$ against adequate matrix matching standard solutions. Recovery efficiencies (\%) were assessed considering concentrations of $\mathrm{K}, \mathrm{Li}$ and $\mathrm{Na}$ found in eluates $\left(\mathrm{C}_{\text {eluate }}\right)$ and those in loaded solutions (C) according to equations $100 \times \mathrm{C}_{\text {eluate }} / 20 \times \mathrm{C}$ or $100 \times \mathrm{C}_{\text {eluate }} / 10 \times \mathrm{C}$. Retention and recovery efficiencies were average values of three independent replicates. Respective column blanks were run and considered in calculations.

\section{Honey samples and pre-concentration procedure}

Four raw honeys, i.e., acacia flower, linden flower, rape flower and multi-flower, directly taken from holding tanks just a few days after their extraction from combs, were from an apiary located in Kostrzyn by the Oder (western Poland, Lubusz Voivodeship, Gorzow County). Additionally, four commercially available (Apis Apiculture Cooperative, Lublin, Poland) honeys of the same type were analyzed. Honeys were stored in plastic containers (raw honeys) or original glass jars in which they were dispatched (commercial honeys).

Before sampling, honeys were homogenized by vigorously stirring with glass rods. Prior to analysis, different amounts of honeys (1.0, 1.5 and $2.5 \mathrm{~g}$ ) were dissolved in water and diluted to $100 \mathrm{~mL}$. A volume of $100 \mathrm{~mL} 10 \%(\mathrm{~m} / \mathrm{v})$ honey solutions were loaded onto SPE columns and driven through $0.7 \mathrm{~g}$ Dowex $50 \mathrm{~W} \times 8-200$ resin 
beds at $6.0 \mathrm{~mL} \mathrm{~min}^{-1}$ to retain $\mathrm{Li}$. Then, SPE columns were washed with water $(10 \mathrm{~mL})$ and submitted to elution with $5.0 \mathrm{~mL}$ of a $1.0 \mathrm{~mol} \mathrm{~L}{ }^{-1} \mathrm{HCl}$ solution at $1.0 \mathrm{~mL} \mathrm{~min}^{-1}$. Respective $5.0 \mathrm{~mL}$ eluate portions, after discarding column dead volumes, were collected and analyzed. Finally, concentrations of $\mathrm{Li}$ in eluates were determined using FOES versus matrix matching (containing $1.0 \mathrm{~mol} \mathrm{~L}^{-1} \mathrm{HCl}$ ) standard solutions. Procedural blanks were considered in the final calculations.

\section{Results and Discussion}

\section{Effect of K, Na, glucose and fructose on Li response}

Potassium and $\mathrm{Na}$ have the highest share in different Polish floral honeys,${ }^{14}$ i.e., to over $3200 \mu \mathrm{g} \mathrm{g} \mathrm{g}^{-1}(\mathrm{~K})$ and up to $100 \mu \mathrm{g} \mathrm{g}^{-1}(\mathrm{Na})$, these metals are also easily ionized in $\mathrm{C}_{2} \mathrm{H}_{2}$-air flames. For that reason, the effect of $\mathrm{K}$ and $\mathrm{Na}$ concentrations on the analytical performance of FOES for $\mathrm{Li}$ was studied in detail. Concentrations of $\mathrm{K}$ and $\mathrm{Na}$ in standard working solutions were changed from 0.50 to $200 \mathrm{mg} \mathrm{L}^{-1}$ and from 0.05 to $10.0 \mathrm{mg} \mathrm{L}^{-1}$, respectively. This corresponded to $5.0 \%(\mathrm{~m} / \mathrm{v})$ solutions of honey in which $\mathrm{K}$ is present at 10 to $4000 \mu \mathrm{g} \mathrm{g}^{-1}$ while $\mathrm{Na}$ at 1 to $200 \mu \mathrm{g} \mathrm{g}^{-1}$. The concentration of $\mathrm{Li}$ in all these solutions was $0.10 \mathrm{mg} \mathrm{L}^{-1}$.

Determining Li concentrations using calibration with aqueous standard solutions it was found that $\mathrm{K}$ and $\mathrm{Na}$ present at studied concentration intervals practically had no effect on intensity signals obtained for the Li emission line. The average Li concentration measured in these conditions was $0.10 \mathrm{mg} \mathrm{L}^{-1}$ with the relative standard deviation (RSD) of $0.5 \%$ for $\mathrm{K}$ and $1.0 \%$ for $\mathrm{Na}$.
In the same way, the separate effect of glucose and fructose as the most abundant constituents of the organic honey matrix was examined. Concentrations of glucose or fructose in standard working solutions were in the range of 3 to $120 \mathrm{~g} \mathrm{~L}^{-1}$ corresponding to 0.4 and $15.0 \%(\mathrm{~m} / \mathrm{v})$ solutions of honey, respectively, in which these simple sugars account for $0.80 \mathrm{~g} \mathrm{~g}^{-1} .{ }^{15}$ Both monosaccharides were found to have a detrimental effect on the analytical performance of FOES for $\mathrm{Li}$ when using calibration with aqueous standard solutions (Figure 1). Physical and chemical interferences related to increasing contents of glucose or fructose in solutions likely affected Li intensity signals since they were gradually suppressed. As a result, concentration of $\mathrm{Li}$ in solutions containing glucose or fructose at $30 \mathrm{~g} \mathrm{~L}^{-1}$ were found to be lower by about 6-7\% than its initial concentration of $0.10 \mathrm{mg} \mathrm{L}^{-1}$ in these solutions. In case of solutions containing $120 \mathrm{~g} \mathrm{~L}^{-1}$ of one of simple sugars, concentrations of Li determined under these conditions were lower by $19-22 \%$ as compared to its initial concentration.

However, when allowable $1.0,1.5$ or $2.5 \%(\mathrm{~m} / \mathrm{v})$ solutions of honey were analyzed, it was impossible to determine Li because its concentration was lower than the respective instrumental LOD assessed for FOES (Table 1). Quite opposite, concentrations of $\mathrm{K}$ and $\mathrm{Na}$ in analyzed honeys, evaluated to be within 190-470 $\mu \mathrm{g} \mathrm{g}^{-1}(\mathrm{~K})$ and 5-170 $\mu \mathrm{g} \mathrm{g}^{-1}(\mathrm{Na})$, were so high that prepared honey solutions required to be subsequently diluted before FOES measurements.

For that reason, it was decided to prepare concentrated honey solutions and separate Li from simple sugars matrix and/or pre-concentrate it before measurements by FOES using SPE.

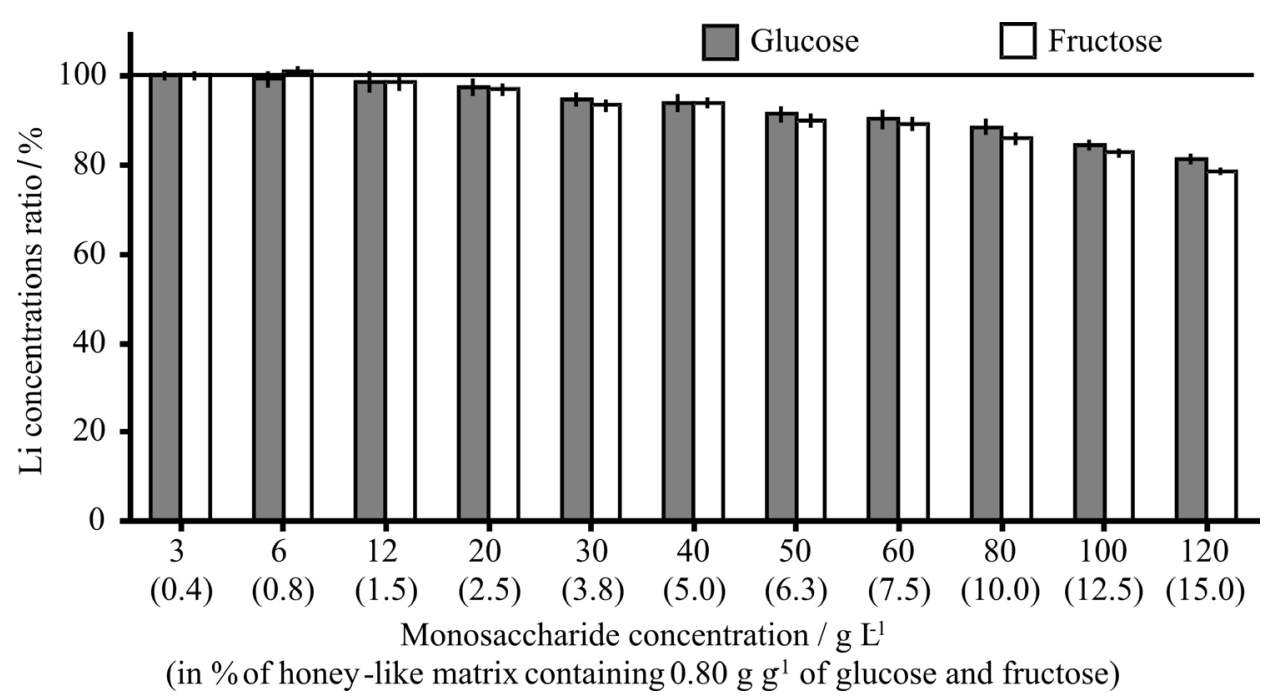

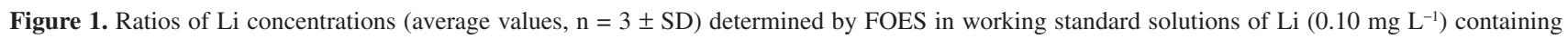
different concentrations of glucose and fructose to its original concentration. Calibration with aqueous standard solutions was used. 
Sorption properties of different polymeric resins toward $K$, $\mathrm{Li}, \mathrm{Na}$, glucose and fructose

The sorption behavior of four different sorbents, i.e., non-ionic Amberlite XAD-7HP, and ionic Dowex 1×4-200, Dowex 50W $\times 8-200$ and Dowex Retardion 11A8, toward $\mathrm{K}, \mathrm{Li}$ and $\mathrm{Na}$ ions, and glucose and fructose was tested as describe above.

On the basis of these measurements (Table 2) it was possible to conclude that only strongly acidic cationexchanger Dowex $50 \mathrm{~W} \times 8-200$ led to a quantitative separation of glucose and fructose from $\mathrm{Li}$ ions at $\mathrm{pH}$ 3.5-5.0. In these conditions, $\mathrm{Li}$ ions were completely retained by the resin along with $\mathrm{K}$ and $\mathrm{Na}$ ions. Considering that much more concentrated solutions of honey would have to be passed through SPE columns to pre-concentrate traces of $\mathrm{Li}$, the effect of glucose and fructose concentrations on retention efficiency of Li by Dowex $50 \mathrm{~W} \times 8-200$ cation-exchanger was studied. Working standard solutions ( $\mathrm{pH} 4.0)$ containing glucose and fructose at concentrations of $40,60,80,100$ and $120 \mathrm{~g} \mathrm{~L}^{-1}$ were used for that purpose.

After analysis of respective column effluents against calibration with matrix matching standard solutions containing the same concentrations of simple sugars, it was found that glucose and fructose did not affect the sorption of alkaline metals by Dowex $50 \mathrm{~W} \times 8-200$. Accordingly, K, $\mathrm{Li}$ and $\mathrm{Na}$ were not detected in collected effluents, while glucose and fructose were determined in these effluents at the same levels as in original solutions loaded onto SPE columns. In the similar way, it was ascertained that retention of $\mathrm{Li}$ ions as well as of $\mathrm{K}$ and $\mathrm{Na}$ ions was quantitative when working standard solutions ( $\mathrm{pH} 4.0$ ) were driven through SPE columns with Dowex $50 \mathrm{~W} \times 8-200$ at much higher flow rates, i.e., 2.0, 4.0, 6.0, 8.0 and $10 \mathrm{~mL} \mathrm{~min}^{-1}$. Additionally, it was assessed that such ions as $\mathrm{Ca}\left(1.0 \mathrm{mg} \mathrm{L}^{-1}\right), \mathrm{Fe}$ (0.2 $\left.\mathrm{mg} \mathrm{L}^{-1}\right), \mathrm{Mg}\left(2.0 \mathrm{mg} \mathrm{L}^{-1}\right), \mathrm{Mn}\left(0.1 \mathrm{mg} \mathrm{L}^{-1}\right)$ and $\mathrm{Zn}$ $\left(0.1 \mathrm{mg} \mathrm{L}^{-1}\right)$, added to working standard solutions of $\mathrm{K}, \mathrm{Li}$ and $\mathrm{Na}(\mathrm{pH} 4.0)$, were also retained by Dowex $50 \mathrm{~W} \times 8-200$ with efficiencies ranged from 92 to $103 \%$ at different flow rates studied, i.e., 1, 2, 4, 6, 8 and $10 \mathrm{~mL} \mathrm{~min}^{-1}$.

A corresponding behavior of Dowex $50 \mathrm{~W} \times 8-200$ toward K, Li and Na ions, glucose and fructose at different flow rates was also established in case of $0.7 \mathrm{~g}$ resin beds. This could result from certain advantages of this gel-type resin, including a high loading capacity and a fast reactivity due to lack of discrete pores. ${ }^{16}$ Consequently, solute ions easily diffuse through particles to interact with ion exchange sites.

Finally, 0.5, 1.0 and $2.0 \mathrm{~mol} \mathrm{~L}-1 \mathrm{HCl}$ solutions were tested for recoveries of $\mathrm{Li}$ from 0.7 and $1.5 \mathrm{~g}$ resin beds of Dowex $50 \mathrm{~W} \times 8-200$ applying 5.0 and $10 \mathrm{~mL}$ portions of these solutions. In case of $1.5 \mathrm{~g}$ resin beds it was found that $10 \mathrm{~mL}$ of a $2.0 \mathrm{~mol} \mathrm{~L}^{-1} \mathrm{HCl}$ solution produce total desorption of $\mathrm{Li}$ ions from SPE columns (Figure 2). Potassium and $\mathrm{Na}$ ions were also quantitatively recovered from the resin under these conditions. For $0.7 \mathrm{~g}$ resin beds,

Table 2. Recoveries (\%) of K, Li, Na and simple sugars from effluents resulted from passing working standard solutions through SPE columns packed with Amberlite XAD-7HP, Dowex 1×4-200 resins, Dowex 50W×8-200 and Dowex Retardion 118A resins

\begin{tabular}{|c|c|c|c|c|c|}
\hline $\mathrm{pH}$ & Constituent & Amberlite XAD-7HP & Dowex $1 \times 4-200$ & Dowex $50 \mathrm{~W} \times 8-200$ & Dowex Retardion 118A \\
\hline \multirow[t]{4}{*}{3.5} & K & $99.1 \pm 1.8$ & $99.2 \pm 1.1$ & $<0.01$ & $100 \pm 1$ \\
\hline & $\mathrm{Li}$ & $100 \pm 1$ & $100 \pm 1$ & $<0.1$ & $100 \pm 1$ \\
\hline & $\mathrm{Na}$ & $104 \pm 1$ & $100 \pm 1$ & $<0.2$ & $100 \pm 1$ \\
\hline & Sugars & $97.1 \pm 1.2$ & $102 \pm 3$ & $101 \pm 1$ & $99.2 \pm 1.2$ \\
\hline \multirow[t]{4}{*}{4.0} & K & $101 \pm 1$ & $98.1 \pm 2.2$ & $<0.01$ & $99.0 \pm 0.9$ \\
\hline & $\mathrm{Li}$ & $99.2 \pm 1.2$ & $100 \pm 1$ & $<0.1$ & $99.4 \pm 0.7$ \\
\hline & $\mathrm{Na}$ & $100 \pm 1$ & $98.4 \pm 1.0$ & $<0.2$ & $98.3 \pm 2.5$ \\
\hline & Sugars & $95.5 \pm 3.2$ & $104 \pm 4$ & $104 \pm 4$ & $104 \pm 5$ \\
\hline \multirow[t]{4}{*}{4.5} & K & $98.4 \pm 0.9$ & $99.3 \pm 2.5$ & $<0.01$ & $101 \pm 2$ \\
\hline & $\mathrm{Li}$ & $99.6 \pm 1.1$ & $98.6 \pm 2.3$ & $<0.1$ & $99.1 \pm 1.3$ \\
\hline & $\mathrm{Na}$ & $99.3 \pm 1.4$ & $98.3 \pm 0.8$ & $<0.2$ & $98.5 \pm 1.0$ \\
\hline & Sugars & $103 \pm 1$ & $104 \pm 3$ & $108 \pm 6$ & $100 \pm 4$ \\
\hline \multirow[t]{4}{*}{5.0} & $\mathrm{~K}$ & $96.7 \pm 3.0$ & $98.4 \pm 1.7$ & $<0.01$ & $98.8 \pm 1.1$ \\
\hline & $\mathrm{Li}$ & $97.3 \pm 2.2$ & $97.8 \pm 1.3$ & $<0.1$ & $100 \pm 1$ \\
\hline & $\mathrm{Na}$ & $98.1 \pm 2.1$ & $96.5 \pm 1.9$ & $<0.2$ & $98.2 \pm 2.1$ \\
\hline & Sugars & $92.6 \pm 9.1$ & $92.9 \pm 4.5$ & $103 \pm 3$ & $102 \pm 6$ \\
\hline
\end{tabular}

Average values $(n=3) \pm S D$. 


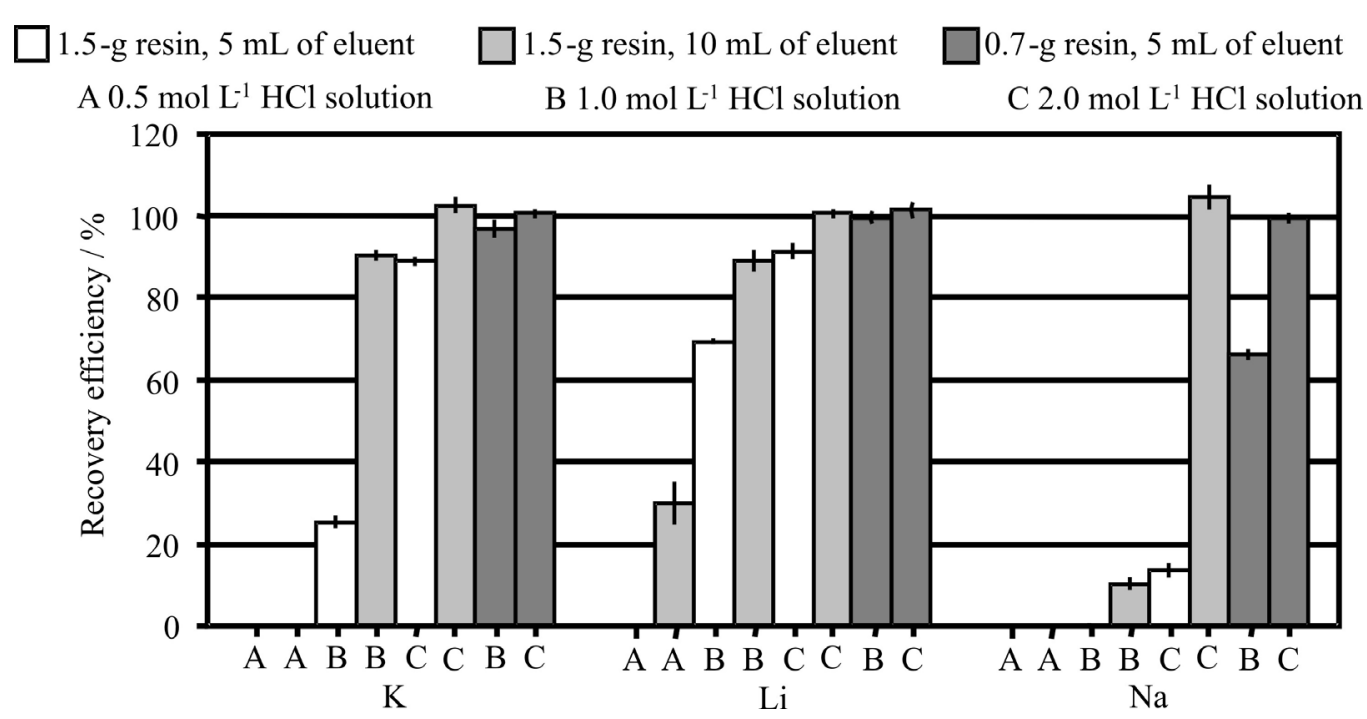

Figure 2. Recovery efficiencies (average values, $\mathrm{n}=3 \pm \mathrm{SD}$ ) of $\mathrm{K}, \mathrm{Li}$ and $\mathrm{Na}$ from Dowex 50W $\times 8-200$ with different $\mathrm{HCl}$ solutions.

already $5.0 \mathrm{~mL}$ portions of 1.0 or $2.0 \mathrm{~mol} \mathrm{~L}^{-1} \mathrm{HCl}$ solutions resulted in total recovery of $\mathrm{Li}$.

\section{Analytical application, pre-concentration and determination of Li in honeys}

To apply the devised Li separation/pre-concentration SPE procedure, $10 \%(\mathrm{~m} / \mathrm{v})$ solutions of analyzed honeys were driven at $6.0 \mathrm{~mL} \mathrm{~min}^{-1}$ through $0.7 \mathrm{~g}$ resin beds of Dowex 50W $\times 8-200$. After loading of honey solutions, SPE columns were washed with $10 \mathrm{~mL}$ of water and then, they were eluted using $5.0 \mathrm{~mL}$ of a $1.0 \mathrm{~mol} \mathrm{~L}^{-1} \mathrm{HCl}$ solution. Respective eluates were collected for determination of the concentration of Li by FOES.

Results of Li determinations are given in Table 3 and they demonstrate that precision (as RSD) of analysis with this method is satisfactory; with typical variations from 8 to $12 \%$, while in case of very low concentrations of $\mathrm{Li}$ it is within $20-25 \%$. To evaluate the accuracy of this method of Li pre-concentration and determination in honey, $10 \%$ $(\mathrm{m} / \mathrm{v})$ solutions of honeys were spiked with $\mathrm{Li}$ so as to double its original content. Next, these sample solutions were treated with Dowex 50W×8-200 SPE columns. It was found that recoveries of added $\mathrm{Li}$ were within $98.0-106 \%$. Additionally, eluates achieved were analyzed by flame atomic absorption spectrometry (FAAS) using the same instrument and against calibration with matrix matching solutions. It was found that comparable concentrations of $\mathrm{Li}$ were determined; differences in results were lower than $20 \%$. This proves the reliability of the proposed sample preparation SPE-based procedure and FOES analysis method. The established method LOD for Li $(3 \times \mathrm{SD}$ of average intensity signal for a SPE procedural blank resulted from passing $100 \mathrm{~mL}$ of water $(\mathrm{pH} 4.0)$ through a
Table 3. Concentrations (in $\mathrm{ng} \mathrm{g}^{-1}$ ) of $\mathrm{Li}$ in raw and commercial floral honeys determined by FOES after Li pre-concentration using SPE with Dowex $50 \mathrm{~W} \times 8-200$ resin

\begin{tabular}{lccc}
\hline & Determined & Added & Recovered \\
\hline Raw honeys & $<0.05$ & 2.0 & $2.0 \pm 0.2$ \\
Acacia & $2.8 \pm 0.3$ & 2.0 & $5.0 \pm 0.4$ \\
Linden & $<0.05$ & 2.0 & $2.1 \pm 0.3$ \\
Rape & $0.4 \pm 0.1$ & 2.0 & $2.5 \pm 0.3$ \\
Multi-flower & & & \\
Commercial honeys & $0.5 \pm 0.1$ & 0.5 & $1.1 \pm 0.2$ \\
Acacia & $5.3 \pm 0.4$ & 5.0 & $10.1 \pm 0.5$ \\
Linden & $1.0 \pm 0.2$ & 1.0 & $2.0 \pm 0.3$ \\
Rape & $1.7 \pm 0.3$ & 2.0 & $3.8 \pm 0.3$ \\
Multi-flower & &
\end{tabular}

Average values $(n=3) \pm S D$.

Dowex $50 \mathrm{~W} \times 8$ column and eluting the resin bed with $5 \mathrm{~mL}$ of a $1.0 \mathrm{~mol} \mathrm{~L}^{-1} \mathrm{HCl}$ solution, $\mathrm{n}=3$ ) was $0.05 \mathrm{ng} \mathrm{g}^{-1}$. This LOD also considered the honey concentration in an analyzed $10 \%(\mathrm{~m} / \mathrm{v})$ solution and the enrichment factor. Considering analysis of a $2.5 \%(\mathrm{~m} / \mathrm{v})$ honey solution, the enrichment factor was 80 , i.e., $(100 \mathrm{~mL} / 5 \mathrm{~mL}) \times(10.0 \mathrm{~g} / 2.5 \mathrm{~g})$.

\section{Conclusions}

Providing a fast SPE procedure based on use of a gel-type strongly acidic cation-exchanger Dowex 50W $\times 8-200$, it was possible to precisely and accurately determine $\mathrm{Li}$ in honeys at a $\mathrm{ng} \mathrm{g}^{-1}$ level by using FOES after its pre-concentration and separation from simple sugars. Considering the retention behavior of the exchanger used, the method proposed could be even simplified when 
applying syringe cartridges or implementing the procedure into a flow-injection analysis mode.

\section{References}

1. Devillers, J.; Dore, J. C.; Marenco, M.; Poirier Duchene, F.; Galand, N.; Viel, C.; J. Agric. Food Chem. 2002, 50, 5998.

2. Bagci, Y.; Arslan, D.; Ozcan, M. M.; Dursun, N.; Int. J. Food Sci. Nutr. 2007, 58, 567.

3. Terrab, A.; Recamales, A. F.; Gonzalez Miret, M. L.; Heredia, F. J.; Food Chem. 2005, 92, 305.

4. Terrab, A.; Hernanz, D.; Heredia, F. J.; J. Agric. Food Chem. 2004, 52, 3441.

5. Gonzalez Miret, M. L.; Terrab, A.; Hernanz, D.; Fernandez Recamales, M. A.; Heredia, F. J.; J. Agric. Food Chem. 2005, 53, 2574

6. Rodriguez Garcia, J. C.; Rodriguez Iglesias, R.; Pena Crecente, R. M.; Garcia, J. B.; Garcia Martin, S.; Herrero Latorre, C.; J. Agric. Food Chem. 2006, 54, 7206.

7. Latorre, M. J.; Pena, R.; Pita, C.; Botana, A.; Garcia, S.; Herrero, C.; Food Chem. 1999, 66, 263.

8. Latorre, M. J.; Pena, R.; Garcia, S.; Herrero, C.; Analyst 2000, $125,307$.
9. Hernnandez, O. M.; Fraga, J. M. G.; Jimenez, A. I.; Jimenez, F.; Arias, J. J.; Food Chem. 2005, 93, 449.

10. Nasiruddin Khan, M.; Qaiser, M.; Mubashir Raza, S.; Rehman, M.; Int. J. Food Sci. Technol. 2006, 41, 775.

11. Welz B.; Sperling, M.; Atomic Absorption Spectrometry, $3^{\text {rd }}$ ed., Wiley-VCH Verlag GmbH.: Weinheim, 1999.

12. Price, W. J.; Spectrochemical Analysis by Atomic Absorption, Heyden \& Son Ltd.: London, 1979.

13. BeMiller, J. N.; Low, N. H. In Food Analysis; Nielsen, S. S., ed.; Aspen Publishers: Gaithersburg, 1998, pp. 167-188.

14. Chudzinska M.; Baralkiewicz, D.; Food Chem. Toxicol. 2010, 48, 284.

15. Fournier, E. In Handbook of Food Analytical Chemistry; Wrolstad, R. E.; Acree, T. E.; Decker, E. A.; Penner, M. H.; Reid, D. S.; Schwartz, S. J.; Shoemaker, C. F.; Smith, D.; Sporns P., eds.; John Wiley \& Sons: New York, 2005, pp. 651-660.

16. Zagorodni, A. A.; Ion Exchange-Materials, Properties and Applications, Elsevier: Amsterdam, 2007.

Submitted: May 18, 2010 Published online: December 14, 2010 